\title{
Topsis Technique in Self-Government - Case Study of Košice Region
}

\author{
Roman Vavrek ${ }^{1, *}$, Ryszard Pukala ${ }^{2}$ \\ ${ }^{1}$ VSB - Technical University of Ostrava, Faculty of Economics, Sokolská třída 33, 70200 Ostrava, \\ Czech Republic \\ ${ }^{2}$ Bronislaw Markiewicz State Higher School of Technology and Economics, Czarnieckiego St. 16, \\ 37-500 Jaroslaw, Poland
}

\begin{abstract}
In the last decades, most of the democratic countries have reallocated tax revenues from collected taxes between the state budget and local government budgets. It is possible to monitor the effort to increase the relative financial autonomy of local governments, to strengthen own revenues of local self-government and to increase the autonomy of decision-making bodies regarding their use. The manuscript focuses on usage of TOPSIS technique as a tool for comprehensive evaluation in selfgovernment in Slovakia. 8 criteria were used and their weight was calculated based Fuller triangle method and 25 experts. Based on this analysis, it is possible to recommend this method for usage not only in public sector, but also in private sector as well. Its use is also conditioned by the appropriate selection of the monitored indicators and their weighting, which significantly determines the overall results.
\end{abstract}

\section{Introduction}

Domestic and foreign researchers [1-5] noted that in the innovation economy, the efficiency evaluation based on multiple criteria is a more complicated option, but on the other hand, this evaluation gives more insight into the real state of public sector efficiency. According to [6], the basic advantage of these methods is the fact that they are not in a position to transform non-economic criteria into economic criteria at the cost of delicate, sometimes controversial operations. These methods include: scales and ranges (can be used separately or as a part of another method), methods of weight determination, methods based on partial evaluation of variants, methods based on pairwise comparison of variants.

All multi-criteria evaluation methods work with criteria (indicators) that are nonnegative and normalized, i.e. their sum is 1 . The method of equal importance is not able to distinguish between the greater or lesser importance of the observed criteria, i.e., all criteria are evaluated equally. Ranking is based on assigning a point value based on certain preferences. The scoring method is similar to the previous method, but works with cardinal variables (preference of individual indicators). The principle of the Fuller's method is to allocate the points to each pair of indicators and then to sum up the points obtained. [7, 8]

\footnotetext{
* Corresponding author: roman.vavrek@,vsb.cz
} 
used this method to evaluate municipalities in the Slovak Republic. Saaty's method works much like the previous methods. The only difference is that it also determines the size of this preference. The weighted sum method is particularly suited to determine quantitative criteria, assuming a linear dependence of the utility rate on criteria (indicators). The basic variant method determines the best or desired values and then calculates the utility rate of each alternative. The lexicographic method is based on the assumption that the most important criterion has the greatest influence. In the case of compliance, the second and the criterion after that shall be taken into account. When solving a problem, the AHP method takes into account all the elements that affect the outcome (the links between them and the intensity with which they influence each other). The TOPSIS method chooses the variant that is closest to the pre-set ideal and at the same time the furthest from the basal variant.

\section{Methodology}

According to [9], TOPSIS enables the decision maker to solve and analyze the problem, to compare alternatives and to rank them on the basis of selected criteria (see also [10-15, 16]).

The identification of individual criteria for TOPSIS calculation was based on personal consultations with government employees of the Financial Control and representatives of municipalities. The common goal was to jointly identify a set of core indicators that best reflect the real status of a particular municipality's economy and that would offer an alternative to the currently valid law-based evaluation.

Table 1. Weights of criteria in two alternatives

\begin{tabular}{|c|c|c|c|c|c|c|c|c|}
\hline criterion & R1 & R2 & R3 & R4 & R5 & R6 & R7 & R8 \\
\hline weight - alterative 1 & 0.161 & 0.113 & 0.150 & 0.123 & 0.09 & 0.144 & 0.106 & 0.113 \\
\hline weight - alterative 2 & 0.125 & 0.125 & 0.125 & 0.125 & 0.125 & 0.125 & 0.125 & 0.125 \\
\hline
\end{tabular}

After several m6eetings, the set was minimized into the following group of monitored indicators:

R1 - total expenditures per capita,

$\mathrm{R} 2$ - share of foreign resources on the total assets of the municipality,

R3 - total income of the municipality per capita,

R4 - profit per inhabitant of the municipality,

R5 - return on assets,

R6 - current expenditures per inhabitant of the municipality,

R7 - foreign sources per inhabitant of the municipality,

R8 - current income per capita of the municipality.

The results of TOPSIS technique are complemented by a set of mathematical and statistical methods, namely Dean Dixon test, Kendall rank coefficient, KolmogorovSmirnov test, Kruskal-Wallis test, Levene test, Moran index, Regression model, and Shapiro-Wilk test as well. For detailed results see also [7, 8, 17, 18].

The whole process of statistical analyzes was carried out in MS Excel, Statistica 13.1 and Statgraphics XVII.

\section{Application of TOPSIS technique in Košice region}

Košice region (KSK) is the second most prosperous region in Slovakia. More than 55 \% of its inhabitants live in the cities. The region is dominated by metallurgical, chemical and electrotechnical industry. 


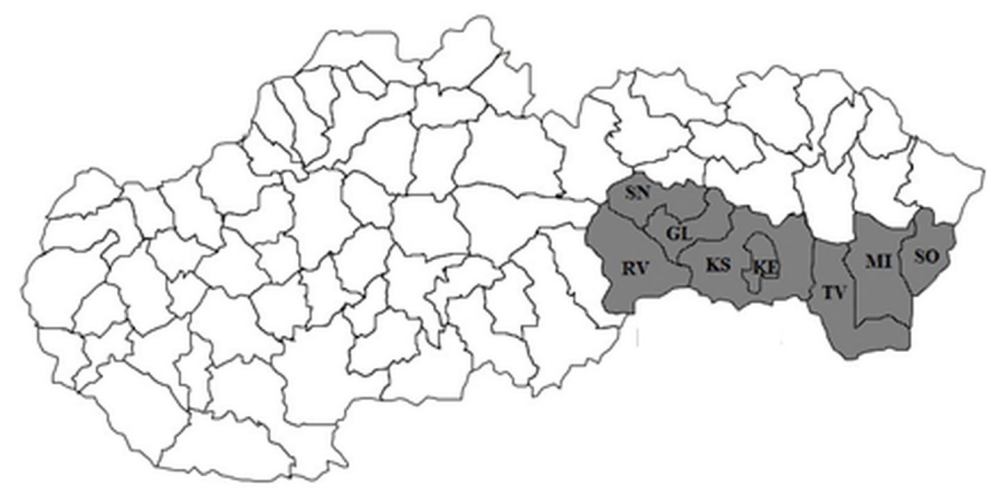

Fig. 1. Districts of Košice region

Košice region has a total of 461 municipalities (including 22 city districts of Košice), of which Košice - Bakša was excluded because of unavailability of data. On average, each municipality has 1721 inhabitants. Since Košice was divided into city districts, the largest statistical unit is Košice - Západ with 40695 inhabitants. The majority group consists of small municipalities $(\mathrm{Q} 3=1175)$, while the basic set is considerably skewed $(\alpha=52.13)$. The smallest municipality is Hanková (62 inhabitants) in the Rožňava district.
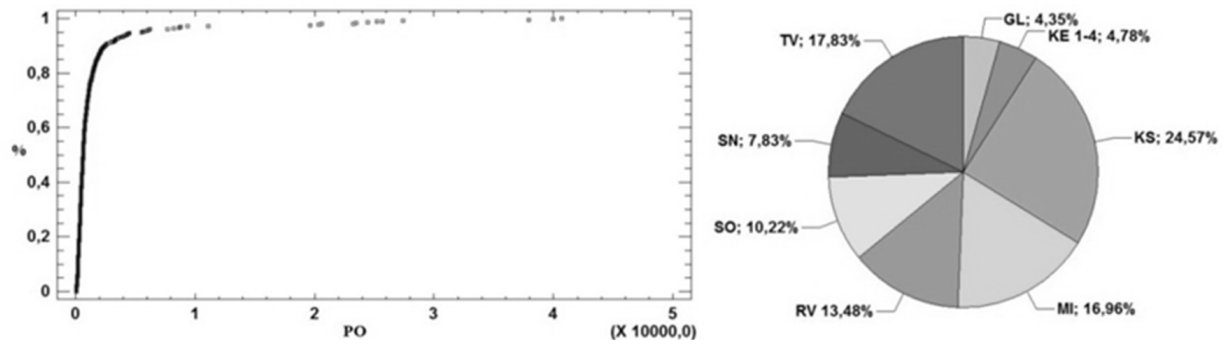

Fig. 2. The structure of KSK municipalities according to the number of inhabitants and districts PO population - municipality size in thousands of inhabitants

\section{Results of TOPSIS method and statistical processing}

The ranking of municipalities achieved by applying the TOPSIS method with the same and modified weights, including the dependence of the individual monitored criteria on the achieved result is outlined in Table 2.

Table 2. Ranking of municipalities based on TOPSIS method - KSK

\begin{tabular}{|c|c|c|c|c|c|c|c|c|c|c|c|c|}
\hline $\mathbf{S}$ & $\mathbf{M}$ & $D^{*}$ & Municipality & $\mathbf{c}_{\mathbf{i}}^{* *}$ & $\mathbf{R}_{1}$ & $\mathbf{R}_{2}$ & $\mathbf{R}_{3}$ & $\mathbf{R}_{4}$ & $\mathbf{R}_{5}$ & $\mathbf{R}_{6}$ & $\mathbf{R}_{7}$ & $\mathbf{R}_{8}$ \\
\hline 1 & 1 & KS & Janík & 0.837 & 301.20 & 18.92 & 583.56 & 344.88 & 0.60 & 301.18 & 107.99 & 296.39 \\
\hline 2 & 2 & RO & Lúčka & 0.821 & 438.36 & 6.66 & 463.95 & 300.11 & 0.41 & 425.82 & 49.10 & 463.95 \\
\hline 3 & 3 & TV & \begin{tabular}{|l|} 
Malý \\
Kamenec
\end{tabular} & 0.820 & 599.56 & 29.25 & 611.03 & 396.94 & 0.41 & 244.76 & 280.73 & 256.23 \\
\hline.. & $\ldots$ & $\ldots$ & $\ldots$ & 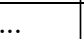 & $2=1$ & & . & & &.. & & \\
\hline 458 & 458 & TV & Trnávka & 0.532 & 163.63 & 187.98 & 170.05 & -15.41 & -0.40 & 163.62 & 73.02 & 163.98 \\
\hline 459 & 459 & KE & $\begin{array}{l}\text { Košice - Dar. } \\
\text { Hrdinov }\end{array}$ & 0.526 & 33.16 & 345.15 & 39.26 & 5.29 & 0.12 & 31.13 & 146.82 & 37.77 \\
\hline 460 & 460 & $\mathrm{SO}$ & Vel'ké Revištia & 0.431 & 425.59 & 5.45 & 456.47 & 686.38 & -1.25 & 419.90 & 29.77 & 446.10 \\
\hline
\end{tabular}




\begin{tabular}{|l|r|r|r|r|r|r|r|r|}
\hline same indicator weights $\left(\mathrm{r}_{\mathrm{K}}\right)$ & 0.105 & -0.217 & 0.165 & 0.681 & 0.683 & 0.093 & -0.126 & 0.149 \\
\hline p-value & 0 & 0 & 0 & 0 & 0 & 0.003 & 0 & 0 \\
\hline modified indicator weights $\left(\mathrm{r}_{\mathrm{K}}\right)$ & 0.085 & -0.217 & 0.156 & 0.679 & 0.658 & 0.072 & -0.124 & 0.131 \\
\hline p-value & 0.007 & 0 & 0 & 0 & 0 & 0.022 & 0 & 0 \\
\hline
\end{tabular}

* district $* *$ ci - relative distance from PIS

For the purposes of further analysis, the remote values identified by the Dean Dixon test were removed (Table 3).

Table 3. Remote values - KSK

\begin{tabular}{|l|l|}
\hline \multicolumn{1}{|c|}{ District } & \multicolumn{1}{c|}{ Statistical unit } \\
\hline Gelnica & Gelnica \\
\hline Košice & Košice - Západ \\
\hline Košice okolie & Čaňa, Moldava nad Bodvou \\
\hline Michalovce & Michalovce, Vel'ké Kapušany \\
\hline Rožňava & Dobšiná, Rožňava \\
\hline Sobrance & Sobrance \\
\hline Spišská Nová Ves & Spišská Nová Ves \\
\hline Trebišov & Trebišov \\
\hline
\end{tabular}

The Kolmogorov-Smirnov test did not confirm any match between the distribution functions of the results of the TOPSIS method (K-S =0,252, p < 0,01). However, the relationship between both distribution functions was confirmed by the Kendall coefficient $(\mathrm{rK}=0,938, \mathrm{p}<0,01)$.

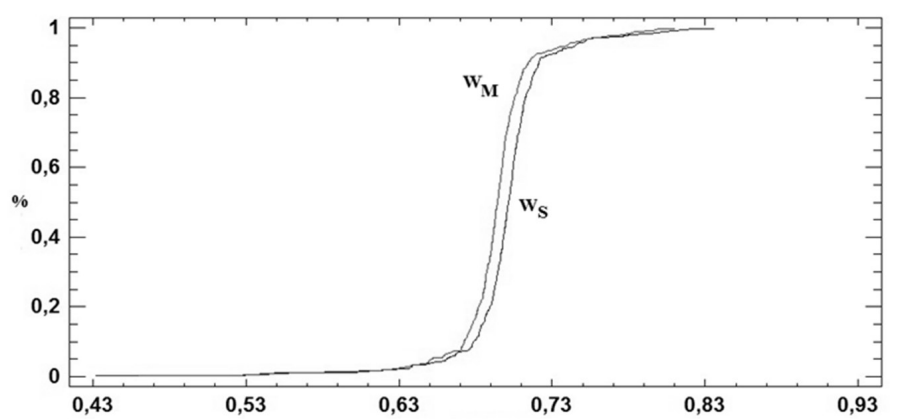

Fig. 3. Comparison of distribution functions of results - KSK WS - distribution function of results of TOPSIS technique with same indicator weights, WM - distribution function of results of TOPSIS technique with modified indicator weights

The Kendall coefficient tests the dependence between the result of the TOPSIS method and the number of inhabitants. This confirmed a weak negative correlation between the monitored variables $\left(\mathrm{rK}=-0.041, \mathrm{p}=0.194 ; \mathrm{rK}^{*}=-0.042, \mathrm{p}=0.180\right)$, however, it was not statistically confirmed.

Table 4. Residue requirements - KSK

\begin{tabular}{|l|l|l|c|}
\hline Requirement & \multicolumn{1}{|c|}{ Test (S) } & \multicolumn{1}{c|}{ Test $(\mathbf{M})$} & Interpretation \\
\hline$\varepsilon_{\mathrm{i}} \sim \mathrm{N}\left(0 ; \sigma_{\varepsilon}^{2}\right)$ & $\mathrm{SW}=0.962, \mathrm{p}<0,01$ & $\mathrm{SW}=0,960, \mathrm{p}<0,01$ & unfulfilled \\
\hline $\mathrm{E}\left(\varepsilon_{\mathrm{i}}\right)=0$ & $\mathrm{E}\left(\varepsilon_{\mathrm{i}}\right)=0.015$ & $\mathrm{E}\left(\varepsilon_{\mathrm{i}}\right)=0,0 . .15$ & fulfilled \\
\hline $\operatorname{cov}\left(\varepsilon_{\mathrm{i}} \varepsilon_{\mathrm{j}}\right)=0$ & Moran $\mathrm{I}=-0.007$ & Moran $\mathrm{I}=-0.004$ & fulfilled \\
\hline $\mathrm{D}\left(\varepsilon_{\mathrm{i}}\right)=\sigma_{\varepsilon}{ }^{2}$ & $\mathrm{~L}_{\mathrm{E}}=8 / 10$ & $\mathrm{~L}_{\mathrm{E}}=10 / 10$ & fulfilled \\
\hline \multicolumn{1}{|c|}{ outliers } & Dean Dixon test & Dean Dixon test & fulfilled \\
\hline
\end{tabular}


Despite $97,5 \%$ ability to explain the variability of results dependent on the size of the statistical unit, estimates of regression functions WS $=0.105261 * \ln (\mathrm{PO})$ or $\mathrm{WM}=$ $0,104227 * \ln (\mathrm{PO})$ cannot be seen as indicative due to the non-fulfillment of the residue prerequisites.

\section{Districts of Košice region}

Change in the weights of the monitored indicators did not change the variance of results in the regions, however, what changed was the median in all districts except Spišská Nová Ves and Trebišov. As the normality of the results was not confirmed in any of the districts, the one-factor variance analysis was not used.

Table 5. Selected characteristics of regions - KSK

\begin{tabular}{|l|c|c|c|}
\hline \multicolumn{1}{|c|}{ District } & Normality & Homoscedasticity & Identical medians \\
\hline Gelnica & no & yes & no \\
\hline Košice & no & yes & no \\
\hline Košice okolie & no & yes & no \\
\hline Michalovce & no & yes & no \\
\hline Rožňava & no & yes & no \\
\hline Sobrance & no & yes & yes \\
\hline Spišská Nová Ves & no & yes & yes \\
\hline Trebišov & no & yes & no \\
\hline
\end{tabular}

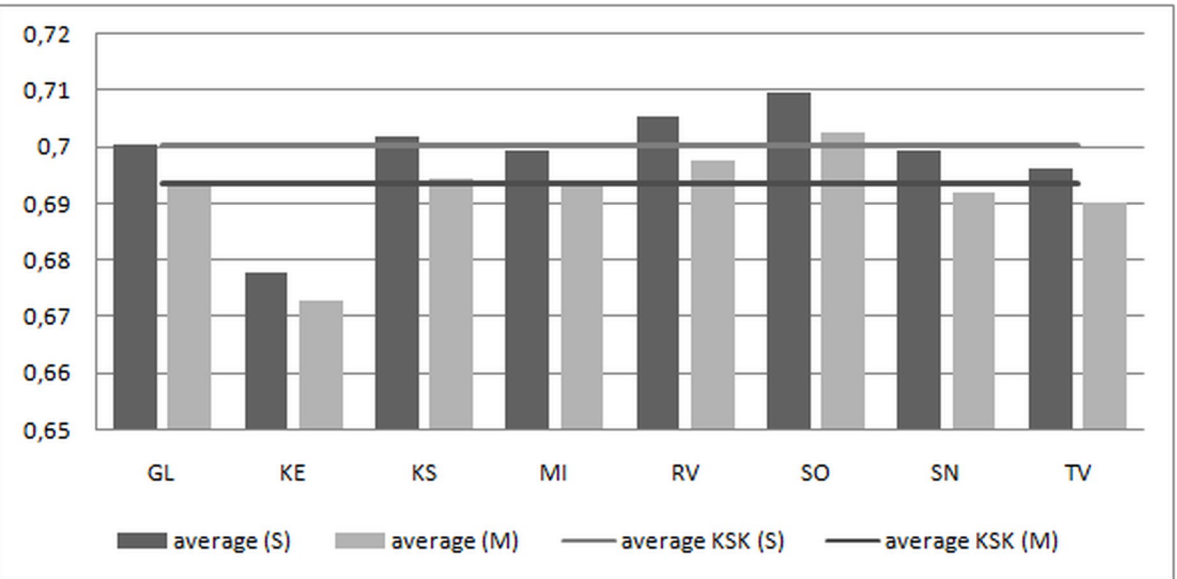

Fig. 4. Average evaluation of municipalities' management in districts of KSK

By comparing the average rating in the districts (Figure 4), we can observe their minimum differences. The best-rated municipalities were found in the Sobrance district. With minimal differences, the worst-rated municipalities were found in the Košice district. Due to the change in monitored weights the evaluation of each district worsened by $0,97 \%$.

The Kruskal-Wallis test in both cases confirmed the statistically significant difference between medians in individual districts $(\mathrm{KW}=23,94, \mathrm{p}<0,01 ; \mathrm{KW}=20,35, \mathrm{p}<0,01)$. The Levene test confirmed their homoscedasticity.

\section{Conclusions}

We consider the TOPSIS method to be a suitable multi-criterion assessment tool for the use of which it is necessary to have financial indicators (which in some cases may limit its use). 
Its use is also conditioned by the appropriate selection of the monitored indicators and their weighting, which significantly determines the overall results. Based on a number of statistical analyzes in KSK we state that:

a) the evaluation of the municipality depends primarily on the result of the management, which also determines the return on assets,

b) the change in the weight, although retaining the variance, changed the median; the average result of the TOPSIS method in individual districts decreased by $0,97 \%$,

c) from the point of view of the evaluation of municipalities the KSK's territory cannot be considered homogeneous.

\section{Acknowledgements}

The paper was created within the financial support of the student grant project SGS No. SP2019/10.

\section{References}

1. M. Petrova, Electronic management in the public sector of Bulgaria (on the example of the regional administrations) 330 (2019)

2. M. Petrova, Informatization of public administration in Bulgaria. Ed. FABER. (Veliko Tarnovo) 428 (2013)

3. M. Petrova, The research of e-Government of the Bulgarian Public Sector Organizations. Business Competences: Monograph, (2012)

4. M. Petrova, Proceeding of the V International Scientific Conference "Innovations in Technology and Education", 102 (2012)

5. M. Petrova, F. Filipov, Improvement of administrative service in Yambol municipal administration, book "E-Justice, e-government and information security", (PSIT-Garant Ltd, Publisher „Znak'94”, Veliko Tarnovo, 2011),

6. J. Rektořík, Ekonomika a řizeni odvětví veřejného sektoru, (Prague: Ekopress, 2007)

7. R. Vavrek, Scientific papers of the University of Pardubice, 24:39, 236 (2017)

8. R. Vavrek, P. Adamišin, R. Kotulič, Polish Journal of Management Studies, 16:2, 290 (2017)

9. H. S. Shih, H. J. Shyur, E. S. Lee, Mathematical and computer modelling. 45:7-8 801 (2007)

10. S. Aouadni, A. Rebai, Z. Turskis, Studies in Informatics and Control. 26:3, 353 (2017)

11. P. W. Bhutia, R. Phipon, Journal of Engineering, 2:10, 43 (2012)

12. A. Kandakoglu, M. Celik, I. Akgun, Mathematical and Computer Modelling, 49:3-4, 586 (2009)

13. A. S. Milani, A. Shanian, C. El-Lahham, Mathematical and Computer Modelling. 48:11-12, $1765(2008)$

14. M. Noryani, S. M. Sapuan, M. T. Mastura, Journal of Mechanical Engineering and Sciences. 12:1, $3330(2018)$

15. S. Opricovic, G. H. Tzeng, Computer-Aided Civil and Infrastructure Engineering. 17:3, 211 (2002)

16. E. K. Zavadskas, A. Mardani, Z. Turskis, A. Jusoh, K. Nor, International Journal of Information Technology \& Decision Making, 15 (2016)

17. R. Vavrek, R. Kotulič, P. Adamišin, Lex localis - Journal of Local Self-Government, 13:2, 249 (2015)

18. R. Vavrek, R. Kotulič, P. AdamiŠin, Journal of Applied Economic Sciences, 9:3, 505 (2014) 